УДК 332.3

\title{
ЦСР-АКЦЕНТУАЦІЯ СІЛЬСЬКОГОСПОДАРСЬКОЇ ЕКОНОМІКИ
}

\section{AGRARIAN ECONOMY AS THE FOCUS OF ACHIEVING SDGS}

\author{
Мареха Ірина Сергіївна \\ кандидат економічних наук, \\ Сумський державний університет \\ ORCID: https://orcid.org/0000-0002-9905-7706 \\ Бондаренко Софія Іванівна \\ студентка, \\ Сумський державний університет \\ ORCID: https://orcid.org/0000-0002-4005-4914
}

\author{
Marekha Iryna, Bondarenko Sofiia \\ Sumy State University
}

\begin{abstract}
У статті послідовно розкривається агроцентричний характер рамкової системи Цілей Сталого Розвитку (ЦСР). Встановлено, що сучасна сільськогосподарська економіка інкорпорує 14 таких Цілей 3-поміж заявлених 17, що дозволяє позиціонувати аграрне природокористування як провідний ЦСР-сектор. 3'ясовано, що ЦСР-землекористування має триопорну структуру, яка включає активи, ринок та інститути. Висувається припущення, що на економічному рівні поняття сталості агросистеми необхідно досліджувати через ії орінансовий стан. У статті проведено оцінку забезпечення сільського господарства інвестиційними ресурсами 3 позицій державного, іноземного та банківського фрінансування. Підкреслено, що сільськогосподарське землекористування виступає не стільки традиційною галуззю економіки, скільки ЦСР-системою.
\end{abstract}

Ключові слова: Цілі Сталого Розвитку, сільське господарство, ЦСР-система, інвестиції, агроцентризм.

В статье последовательно раскрывается агроцентрический характер рамочной системы Целей Устойчивого Развития (ЦУР). Установлено, что современная сельскохозяйственная экономика инкорпорирует 14 таких целей из 17 заявленных, что позволяет позиционировать аграрное природопользование как ведущий ЦУР-сектор. Определено, что ЦУР-землепользование имеет трехопорную структуру, которая включает активы, рынок и институты. Предполагается, что на экономическом уровне понятие устойчивости агросистемы необходимо исследовать через ее фринансовое состояние. В статье проведено оценку обеспечения сельского хозяйства инвестиционными ресурсами с позиций государственного, иностранного и банковского фринансирования. Подчеркнуто, что сельскохозяйственное землепользование выступает не столько традиционной отраслью экономики, сколько ЦУР-системой.

Ключевые слова: Цели Устойчивого Развития, сельское хозяйство, ЦУР-система, инвестиции, агроцентризм.

The main objective of the article is to give an understanding that agrarian economy is the main focus of achieving Sustainable Development Goals (SDGs). SDGs were declared within the Agenda 2030 and imply the following options with respect to sustainable agriculture: combating poverty (SDG-1); reducing inequality (SDG-10); zero hunger (SDG-2); strong health (SDG-3); qualitative education (SDG-4); innovations and infrastructure (SDG-9); gender equality (SDG-5); renewable energy (SDG-7); decent work and economic growth (SDG-8); responsible consumption and production (SDG-12); combating climate change (SDG-13); preservation of ecosystems (SDG-15); peace and justice (SDG-16); partnerships (SDG-17). In the article, the following research methods were used: grouping and systematization - when distinguishing SDGs most applicable to agriculture and shaping three-pillar structure of SDG-agriculture; computational techniques - when analyzing statistical data collected from the official web-sites of Food and Agricultural Organization and Ministry for Agrarian Policy and Food of Ukraine; system analysis and comparison - in the study of investment profile of agriculture on the global and national scale. Based on sustainable development approach, we shaped three-pillar structure for SDG-agriculture which includes assets (environmental component), market (economic element), and institutions (social and political constituents). It was emphasized in the article, that economic implications of sustainable agriculture can be analyzed via estimation of its financial conditions 
and support. For doing so, several investment strategies were selected as an object for statistical analysis, namely government expenditures, foreign direct investments, and bank loans. In addition, the agriculture orientation index for government expenditures was calculated and analyzed in dynamics. We revealed the relation between the period SDGs were developed (2015) and the rise in government support to agriculture (since 2015 this indicator increased its value). The practical significance of the conducted research is that it gives the evidence from national and international practice how agriculture serves as the main focus in achieving SDGs.

Keywords: Sustainable Development Goals, agriculture, SDG-system, investments, agricentrism.

Постановка проблеми. Сільське господарство як система, що найбільш тісно пов'язана з навколишнім середовище, в умовах глобальних екологічних викликів поступово переходить на новий рівень екопросторового розвитку. Агроцентрична модель сільської економіки, що відповідає за виробництво продовольчої продукції та постачання сировини, поступово транссрормується у поліфункціональну систему з наближенням до руральної ідеології [1, с. 13], яка $\epsilon$ альтернативою фрілософрії споживання. Наразі особливою популярністю користується альтернативне землекористування як спосіб переходу від техногенної індустріальної системи до сталого природокористування. Розвиток нових, сталих методів ведення сільського господарства відбувається у фрормі «екологічного», «органічного», «біологічного», «динамічно адаптивного», «розумного» та «кліматично оптимізованого» землекористування. Перебуваючи у перманентному зв'язку між добробутом населення та природними ресурсами планети, стале сільськогосподарське землекористування володіє потужним потенціалом для розв'язання глобальних проблем сьогодення. Так, сталий аграрний сектор забезпечує доступність харчування, засоби до існування, а також інклюзивне національне зростання і стимулює позитивні перетворення у відповідності до Порядку денного на період до 2030 року. 3 цією метою і було розроблено рекомендації щодо трансформації сільського господарства у напрямку розбудови Цілей Сталого Розвитку (ЦСР) [2]. Актуальність зазначеної проблематики обумовила вибір об'єкта дослідження.

Аналіз останніх досліджень і публікацій. Дослідження аграрного сектору 3 точки зору імплементації Цілей Сталого Розвитку $\epsilon$ відносно новим явищем для вітчизняної та зарубіжної науки. Традиційний інтерес до сільського господарства як соціо-еколого-економічної системи проявляють Іванов В. О., Пономарьова А. С. [3] та ін. Декомпозиція складових сталого розвитку простежується у роботах Страпчук С. [4], Гаращук О. В. [5], Рощиної Ю. В. [6], Погріщук В. Б. [7], Мішені- ної Н. В. [8], Мацибори Т. В. [9] та ін. В цілому, на даному етапі розвитку заявленій у даній статті проблематиці присвячуються аналітичні публікації та доповіді ФАО [11], а також Національний стратегічний документ [12]. Зважаючи на новизну окресленого об'єкта дослідження, відзначимо, що існуючі напрацювання можуть використовуватися у якості методологічного підґрунтя та інструментарію для подальшого аналізу й послідовного удосконалення економічних підходів щодо дослідження сталості сільськогосподарського розвитку.

Формулювання цілей статті. Метою статті $€$ обґрунтувати агроцентричність рамкової системи показників ЦСР та дослідити аграрне природокористування як ЦСР-систему з використанням економічного підходу.

Виклад основного матеріалу дослідження. На Порядку денному на період до 2030 року було затверджено комплексну рамкову систему показників ЦСР. Ми вважаємо, що дана система за своєю сутністю $є$ агроцентричною (таблиця 1).

Використовуючи методологію сталого розвитку, можна стверджувати, що ЦСРземлекористування повинно мати триопорну структуру (рис. 1):

1. Ринок (ЦСР: 1, 10, 8, 12) - включає попит на продовольство, пропозицію сільгосптоваровиробників, стан фрінансування галузі, цінову політику, конкурентоспроможність на вітчизняному й закордонному агропродовольчому ринках тощо.

2. Активи (ЦСР: 2, 3, 7, 13, 15) - включають природний капітал, земельний банк країни, агроекологічний стан ґрунтів, якість продовольства тощо.

3. Інститути (ЦСР: 4, 9, 5, 16, 17) - містять політичні (державне регулювання прав земельної власності) та соціальні (культура, менталітет, гендер) інститути. Особливо актуальним $є$ для України в умовах проведення земельної реформи та трансорормації прав на земельну власність.

На економічному рівні поняття сталості агросистеми, як правило, прийнято досліджувати через її фрінансовий стан. Результати комплексного аналізу сільськогосподарської 
Інкорпорація ЦСР у сферу аграрного природокористування

\begin{tabular}{|c|c|c|}
\hline ЦСР & Цілі & Роль галузі \\
\hline 1,10 & $\begin{array}{l}\text { Подолання бідності, } \\
\text { скорочення нерівності }\end{array}$ & $\begin{array}{l}\text { Зростання ВВП, обумовлене зростанням сільського } \\
\text { господарства, щонайменше удвічі ефективніше сприяє } \\
\text { скороченню бідності серед населення, ніж зростання ВВП, } \\
\text { отримане за рахунок інших галузей економіки. }\end{array}$ \\
\hline 2,3 & $\begin{array}{l}\text { Подолання голоду, } \\
\text { міцне здоров'я }\end{array}$ & $\begin{array}{l}\text { Майже } 800 \text { млн людей потерпає від недоїдання, а кожен } \\
\text { третій не має доступу до якісної іжі. Агробізнес відіграє } \\
\text { провідну, стратегічну роль у постачанні продовольства, } \\
\text { достатні обсяги та висока екологічна якість якого } \\
\text { кардинальним чином відбиваються на покращенні здоров'я } \\
\text { та збільшення тривалості життя людей планети. }\end{array}$ \\
\hline 4,9 & $\begin{array}{l}\text { Якісна освіта, інновації } \\
\text { та індрраструктура }\end{array}$ & $\begin{array}{l}\text { Зростання населення планети та попиту на продовольство } \\
\text { потребують застосування інноваційних технологій } \\
\text { землекористування, що обумовлює необхідність в } \\
\text { агрономічних знаннях, наукових дослідженнях та державних } \\
\text { інвестиціях в якісну аграрну освіту. }\end{array}$ \\
\hline 5 & Гендерна рівність & $\begin{array}{l}\text { Вирівнювання можливостей доступу до виробничих } \\
\text { ресурсів між чоловіками та жінками сприяє підвищенню } \\
\text { продуктивності господарств на 20-30\%, що може знизити } \\
\text { кількість голодуючих у світі на 12-17\%. }\end{array}$ \\
\hline 7 & Відновлювана енергія & $\begin{array}{l}\text { Земельні ресурси виконують новітню економічну функцію } \\
\text { - енергетичну, виступаючи джерелом постачання } \\
\text { сільськогосподарської біомаси. }\end{array}$ \\
\hline 8 & $\begin{array}{l}\text { Гідна праця та } \\
\text { економічне зростання }\end{array}$ & $\begin{array}{l}\text { Один працюючий у сільському господарстві забезпечує } \\
\text { роботою } 8 \text { працюючих в інших галузях. Фермерські } \\
\text { господарства диверсифікують продовольчі системи, які } \\
\text { можуть створювати робочі місця та гідні умови оплати праці } \\
\text { за умови інвестицій, що позитивно впливає на підвищення } \\
\text { престижу землеробської праці та економічне зростання. }\end{array}$ \\
\hline 12 & $\begin{array}{l}\text { Відповідальне } \\
\text { споживання та } \\
\text { виробництво }\end{array}$ & $\begin{array}{l}\text { Перехід на ресурсоесрективну модель виробництва } \\
\text { продукції землеробства є актуальним трендом у сучасному } \\
\text { міжнародному аграрному бізнесі. Раціоналізація споживання } \\
\text { досягається шляхом впливу на екологічну свідомість } \\
\text { громадян. }\end{array}$ \\
\hline 13 & $\begin{array}{l}\text { Боротьба зі зміною } \\
\text { клімату }\end{array}$ & $\begin{array}{l}\text { Фермерські господарства володіють суттєвим природним } \\
\text { потенціалом пом'якшення негативних наслідків глобальної } \\
\text { зміни клімату. За умови екологічної конверсії такий потенціал } \\
\text { зростає в рази. Наразі зусилля спрямовуються у кліматично } \\
\text { оптимізоване (climate-smart) сільське господарство. }\end{array}$ \\
\hline 15 & $\begin{array}{l}\text { Збереження екосистем } \\
\text { суші }\end{array}$ & $\begin{array}{l}\text { Раціональне сільськогосподарське землекористування є } \\
\text { запорукою збереження природних компонентів еколого- } \\
\text { економічних систем. }\end{array}$ \\
\hline 16 & Мир та справедливість & $\begin{array}{l}\text { Традиційно народи, що займаються переважно сільським } \\
\text { господарством, не нарощують свій військовий потенціал, а } \\
\text { тому землекористування є «мирним» заняттям. }\end{array}$ \\
\hline 17 & $\begin{array}{l}\text { Партнерство заради } \\
\text { стійкого розвитку }\end{array}$ & $\begin{array}{l}\text { Державно-приватне партнерство та сільськогосподарські } \\
\text { кооперативи є поширеною фрормою ведення агробізнесу. } \\
\text { Кооперація у такому разі є ефективним використанням } \\
\text { природних ресурсів. }\end{array}$ \\
\hline
\end{tabular}

Джерело: авторська розробка на основі [11]

економіки за критерієм «РИНОК» представлено на рис. 2.

Як видно з рис. 2, Індекс агроорієнтованості світового аграрного ринку у 5 разів перевищує аналогічний вітчизняний показник. Це може бути пояснено недостатнім фрінансу- ванням бюджетних видатків сільськогосподарського спрямування в Україні. Проте у світовому масштабі державне інвестування сільського господарства перевищує 2 \% від ВВП, починаючи з 2015 року, - року, в якому були задекларовані ЦСР (рис. 3). Це свідчить 


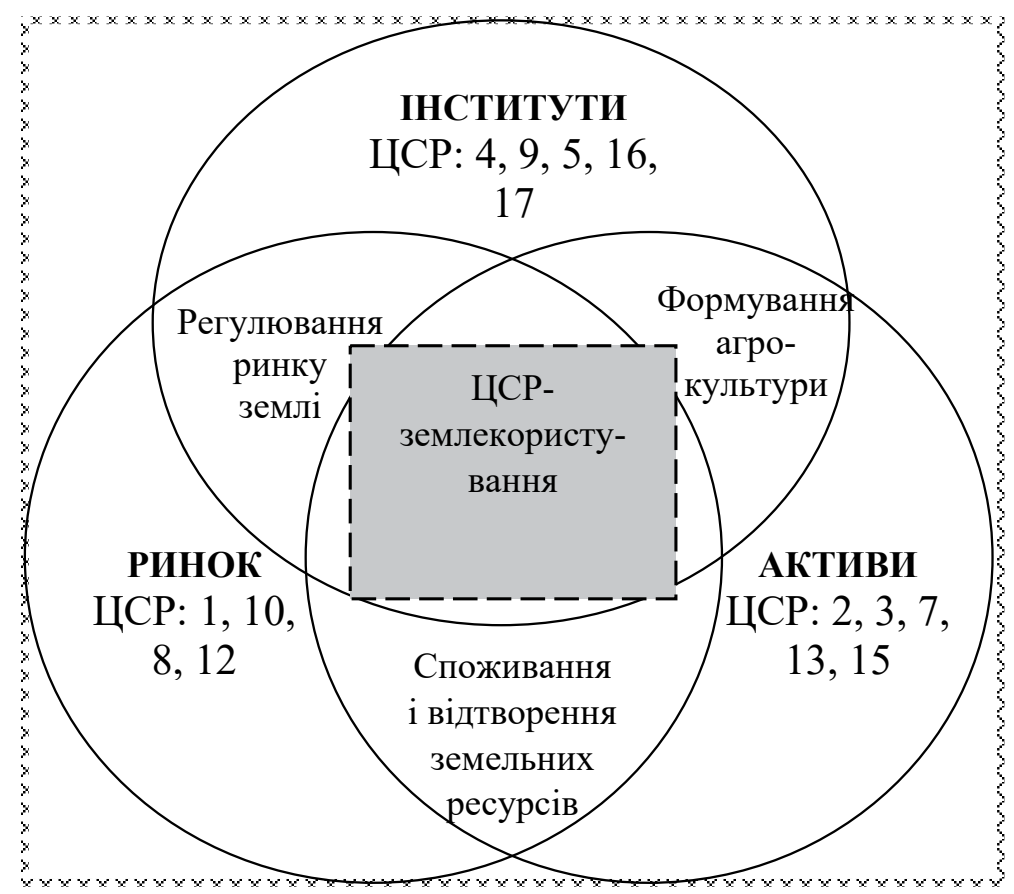

Рис. 1. Аграрне природокористування як ЦСР-система

Джерело: авторська розробка

про дієвість та есрективність Стратегії на міжнародному рівні.

Особливу зацікавленість викликає стан інвестування аграрного сектору в Україні 3 точки зору державного, іноземного та банківського фрінансування (таблиці 2-4).

У таблиці 2 наведено класифрікацію бюджетних видатків за класифрікацією

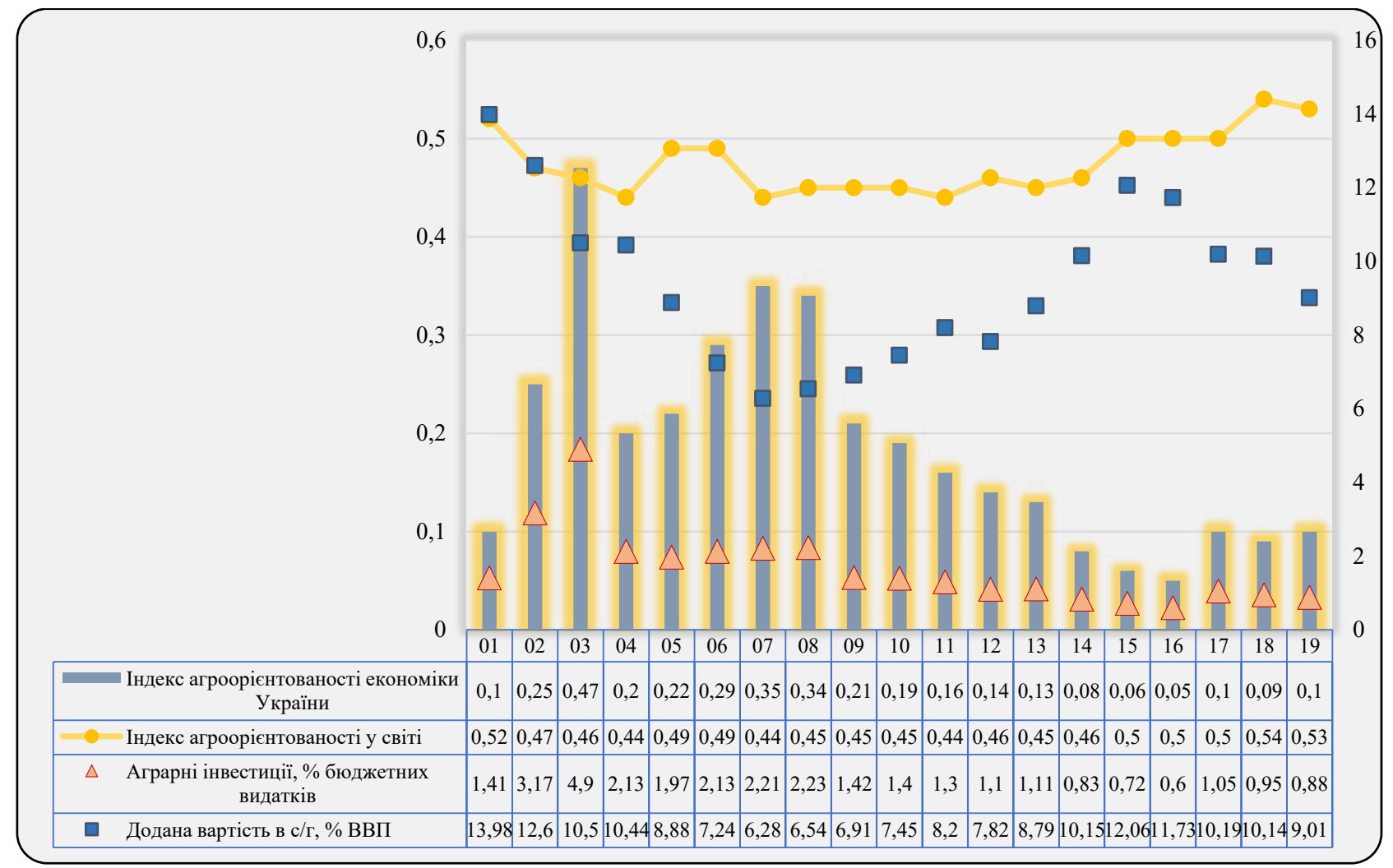

Рис. 2. Індекс агроорієнтованості ринку

Джерело: авторські розрахунки на основі [10] 


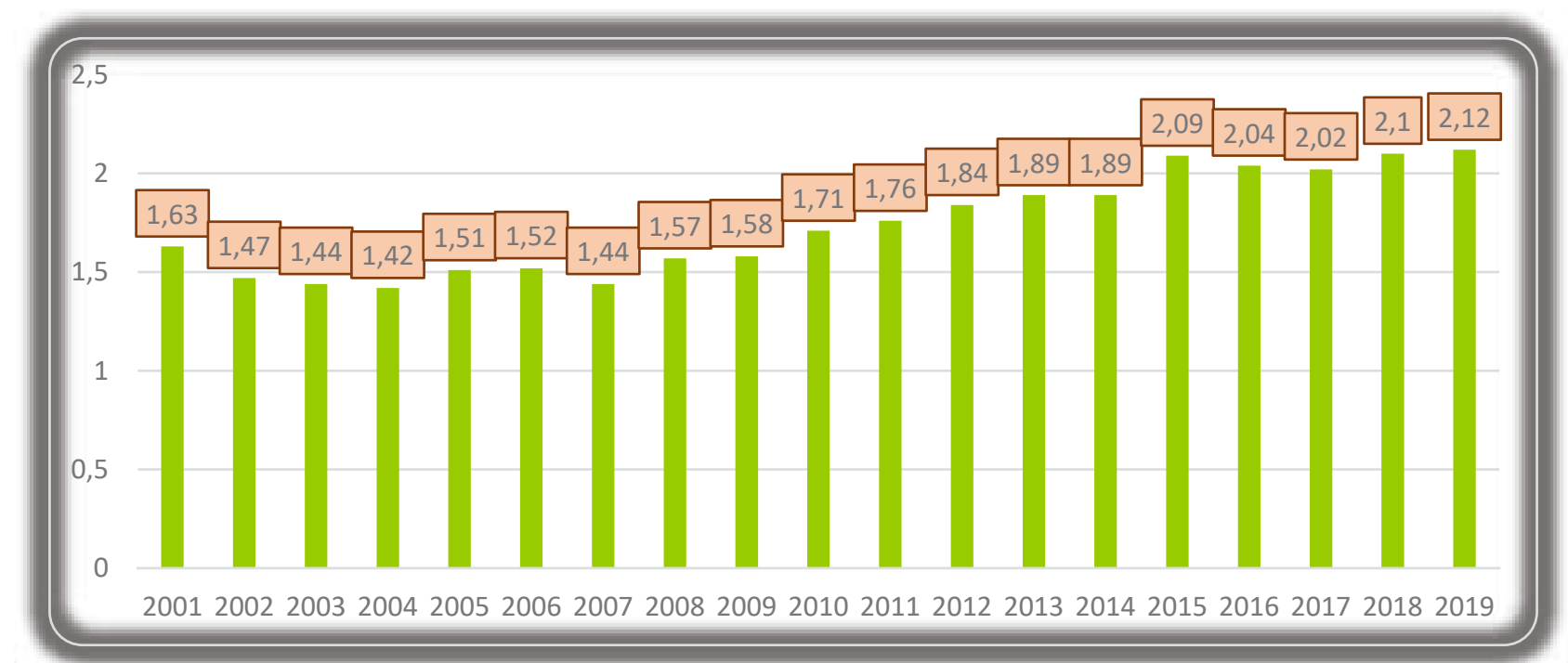

Рис. 3. Аграрні бюджетні інвестиції, \% ВВП

Джерело: авторські розрахунки на основі [10]

СОТ. Так, об'єкти жовтої скриньки (субсидії) повинні підлягати скороченню, а зеленої - нарощуванню. Проте наразі така структура не дотримується, оскільки, згідно 3 додатковими розрахунками, інвестиції у заходи жовтої скриньки у 2021 році ста- новили 98 \% проти 2 \% видатків зеленого спрямування.

У таблиці 3 міститься інформація щодо частки прямих іноземних інвестицій в аграрному ВВП України та у країнах 3 потужною сільськогосподарською орієнтацією. Як

Структура національних бюджетних видатків згідно з таксономією Сот

\begin{tabular}{|l|c|c|c|c|c|c|c|}
\hline $\begin{array}{c}\text { Напрями } \\
\text { інвестування }\end{array}$ & $\mathbf{2 0 1 5}$ & $\mathbf{2 0 1 6}$ & $\mathbf{2 0 1 7}$ & $\mathbf{2 0 1 8}$ & $\mathbf{2 0 1 9}$ & $\mathbf{2 0 2 0}$ & $\mathbf{2 0 2 1}$ \\
\hline \multicolumn{7}{|c|}{ Жовта скринька } \\
\hline Прямі субсидії & 0,45 & 0,1 & 0,12 & 0,78 & 0,67 & 0,1 & 0,03 \\
\hline Непрямі субсидії & 0,55 & 0,9 & 0,88 & 0,22 & 0,33 & 0,9 & 0,97 \\
\hline \multicolumn{7}{|c|}{ Зелена скринька } \\
\hline Освіта & 0,04 & 0,13 & 0,07 & 0,08 & 0,09 & 0,07 & 0,18 \\
\hline Наука & 0,21 & 0,82 & 0,51 & 0,50 & 0,51 & 0,39 & 0,82 \\
\hline Охорона довкілля & 0,01 & 0,05 & 0,06 & 0,08 & 0,05 & 0,06 & 0,00 \\
\hline Продовольча безпека & 0,46 & 0,00 & 0,36 & 0,34 & 0,35 & 0,48 & 0,00 \\
\hline Лізинг & 0,25 & 0,00 & 0,00 & 0,00 & 0,00 & 0,00 & 0,00 \\
\hline Охорона здоров'я & 0,03 & 0,00 & 0,00 & 0,00 & 0,00 & 0,00 & 0,00 \\
\hline
\end{tabular}

Джерело: авторські розрахунки на основі [12]

Таблиця 3

Фінансування сільського господарства через механізм ПІІ

\begin{tabular}{|c|c|c|c|c|c|}
\hline Країна & 2015 & 2016 & 2017 & 2018 & 2019 \\
\hline Україна & 0,07 & 0,07 & 0,06 & 0,05 & 0,06 \\
\hline Польща & 0,52 & 0,51 & 0,28 & 0,44 & 0,42 \\
\hline Франція & 0,74 & 0,4 & 0,41 & 0,66 & 0,58 \\
\hline Німеччина & 0,58 & 0,3 & 1,16 & 1,51 & 0,73 \\
\hline Нідерланди & 9,98 & 1,66 & 3,27 & 6,58 & 4,69 \\
\hline
\end{tabular}

Джерело: авторські розрахунки на основі [10] 
Банківське кредитування сільськогосподарської економіки

\begin{tabular}{|l|c|c|c|c|c|}
\hline \multicolumn{1}{|c|}{ Країна } & $\mathbf{2 0 1 5}$ & $\mathbf{2 0 1 6}$ & $\mathbf{2 0 1 7}$ & $\mathbf{2 0 1 8}$ & $\mathbf{2 0 1 9}$ \\
\hline Україна & 0,05 & 0,047 & 0,049 & 0,051 & 0,048 \\
\hline Франція & 0,87 & 0,95 & 0,93 & 1,06 & 1,03 \\
\hline Німеччина & 1,04 & 1,07 & 1,08 & 1,28 & 1,21 \\
\hline Нідерланди & 2,25 & 2,15 & 2,1 & 2,28 & 2,03 \\
\hline Австралія & 1,13 & 1,2 & 1,18 & 1,32 & 1,45 \\
\hline Канада & 0,39 & 0,38 & 0,41 & 0,46 & 0,49 \\
\hline США & 0,0002 & 0,0002 & 0,0002 & 0,0002 & 0,0002 \\
\hline
\end{tabular}

Джерело: авторські розрахунки на основі [10]

видно, українська економіка є найменш відкритою 3-поміж досліджуваних країн.

У таблиці 4 репрезентовано дані стосовно банківського кредитування галузі як частки від аграрного ВВП. Такі держави, як США та Україна не достатньою мірою покладаються на банківські кредити. Так, в Україні зокрема, ставка позичкового капіталу перевищує рентабельність агропідприємств, що ускладнює процедуру залучення коштів.

Висновки 3 дослідження і дальші перспективи в цьому напрямку. У статті здійснено спробу акцентуації сільськогосподарської економіки на досягненні Цілей Сталого Розвитку та доведено агроцентричний характер рамкової системи зазначених показників. У сучасних умовах розбудови сталого розвитку сільськогосподарське землекористування виступає не стільки традиційною галуззю суспільного виробництва, скільки ЦСР-системою, що інтегрує 14 цілей 3-поміж задекларованих 17. Як було встановлено в роботі, рамкова система показників ЦСР носить не лише декларативний характер, а й ефективно позначається на стані фрінансування аграрного сектору у світовому масштабі. Перспективами подальших досліджень мають стати оцінки ступеня виконання національних таргетів у рамках ЦСР-2, що передбачає забезпечення продовольчої безпеки в країні та інклюзивний розвиток сільського господарства.

\section{СПИСОК ВИКОРИСТАНИХ ДЖЕРЕЛ:}

1. Куцмус Н.М. Гендерні імперативи розвитку сільської економіки в умовах глобалізації : монографрія. Київ : ЦУЛ, 2018. 293 с.

2. Transforming Food and Agriculture to Achieve the SDGs. 20 Interconnected Actions to Guide DecisionMakers. FAO. Rome, 2018. 76 p.

3. Иванов В.А., Пономарева А.С. Методологические основы устойчивого развития аграрного сектора. Экономические и социальные перемены: фракты, тенденции, прогноз. 2011. № 4. С. 109-121.

4. Страпчук С. Соціальна складова сталого розвитку сільськогосподарських підприємств. Економічний аналіз. 2020. Том 30. № 3. C. 258-267. DOI: http://dx.doi.org/10.35774/econa2020.04.258

5. Гаращук О.В. Соціальна складова національної безпеки та сталого розвитку в умовах глобалізації. Економічний аналіз. 2017. Том 27. № 1. С. 28-34.

6. Рощина Ю.В. Диалектика сущности десриниций «Природные ресурсы», «Аграрное природопользование» и его «Устойчивое развитие». Управление экономическими системами: электронный научный журнал. 2017. № 6. URL: https://cyberleninka.ru/article/n/dialektika-suschnosti-definitsiy-prirodnye-resursy-agrarnoeprirodopolzovanie-i-ego-ustoychivoe-razvitie

7. Погріщук В.Б. Екологічні засади розвитку аграрної економіки у концепції сталого розвитку. Вісник ХНАУ ім. В.В. Докучаєва. Серія «Економічні науки». 2019. № 4. Т. 1. С. 368-377. DOI: https://doi.org/10.31359/23123427-2019-4-1-368

8. Мішеніна Н.В., Мареха І.С. Стратегії інвестиційного забезпечення сталого розвитку аграрного сектору економіки України. Український журнал «Економіст». 2011. № 1. С. 33-38.

9. Мацибора Т.В. Інвестиційний потенціал аграрного сектору України: фрормування та розвиток. Економіка АПК. 2020. № 6. C. 49-58. DOI: https://doi.org/10.32317/2221-1055.202006049

10. Офріційний сайт ФАО. URL: https://www.fao.org/statistics/en/

11. Цілі, адаптовані для України. Цілі Сталого Розвитку: Україна. Національна доповідь. Міністерство економічного розвитку і торгівлі України, 2017. 176 с. 
12. Офріційний сайт Міністерства аграрної політики та продовольства України. URL: https://minagro.gov.ua/ua

\section{REFERENCES:}

1. Kutsmus N.M. (2018) Henderni imperatyvy ekonomichnoho rozvytku sela $v$ umovakh hlobalizatsiyi [Gender imperatives of rural economic development in the context of globalization]. Kyiv: TSUL, 293 p. (in Ukrainian)

2. Transforming Food and Agriculture to Achieve the SDGs. 20 Interconnected Actions to Guide Decision-Makers (2018). FAO, Rome, 76 p.

3. Ivanov V.A., Ponomareva A.S. (2011) Metodologicheskiye osnovy ustoychivogo razvitiya agrarnogo sektora [Methodological foundations for sustainable development of the agricultural sector]. Ekonomicheskiye i sotsial'nyye peremeny: fakty, tendentsii, prognoz [Economic and social changes: facts, trends, forecast], no. 4, pp. 109-121. (in Russian)

4. Strapchuk S. (2020) Sotsial'na skladova staloho rozvytku sil's'kohospodars'kykh pidpryyemstv [Social component of sustainable development of agricultural emterprises]. Ekonomichnyy analiz [Economic analysis], no. 3, vol. 3, pp. 258-267. Available at: http://dx.doi.org/10.35774/econa2020.04.258 (in Ukrainian)

5. Garashchuk O.V. (2017) Sotsial'na skladova natsional'noyi bezpeky ta staloho rozvytku v umovakh hlobalizatsiyi [The social component of the national security and sustainable development in the context of globalization]. Ekonomichnyy analiz [Economic analysis], no. 1, vol. 27, pp. 28-34. (in Ukrainian)

6. Roshchina J.V. (2017) Dialektika sushchnosti definitsiy «Prirodnyye resursy», «Agrarnoye prirodopol'zovaniye» i yego «Ustoychivoye razvitiye» [Dialectics of the essence of definitions natural resources, agrarian nature management and him sustainable development]. Upravleniye ekonomicheskimi sistemami: elektronnyy nauchnyy zhurnal [Management of economic systems: electronic scientific journal], no. 6. Available at: https://cyberleninka.ru/ article/n/dialektika-suschnosti-definitsiy-prirodnye-resursy-agrarnoe-prirodopolzovanie-i-ego-ustoychivoe-razvitie (in Russian)

7. Pogrischuk B.V. (2019) Ekolohichni zasady rozvytku ahrarnoyi ekonomiky u kontseptsiyi staloho rozvytku [Environmental principles of agrarian economy development in the concept of sustainable development]. Visnyk KHNAU im. V.V. Dokuchayeva. Seriya «Ekonomichni nauky» [Bulletin of KhNAU named after V.V. Dokuchaeva. Economic Sciences Series], no. 4, vol. 1, pp. 368-377. Available at: https://doi.org/10.31359/2312-3427-2019-4-1-368 (in Ukrainian)

8. Mishenina N.V., Marekha I.S. (2011) Stratehiyi investytsiynoho zabezpechennya staloho rozvytku ahrarnoho sektoru ekonomiky Ukrayiny [The investment strategies for providing sustainable development of agrarian sector of Ukraine]. Ukrayins'kyy zhurnal «Ekonomist» [The Ukrainian journal «Economist»], no. 1, pp. 33-38. (in Ukrainian)

9. Matsybora T.V. (2020) Investytsiinyi potentsial ahrarnoho sektoru Ukrainy: formuvannia ta rozvytok [Investment potential of the agrarian sector of economy of Ukraine: formation and development]. Ekonomika APK [Economics of agri-food complex], no. 6, pp. 49-58. Available at: https://doi.org/10.32317/2221-1055.202006049 (in Ukrainian)

10. Official web-site of FAO. Available at: https://www.fao.org/en/

11. Natsionalna dopovid [National report] (2017) Tsili, adaptovani dlya Ukrayiny. Tsili Staloho Rozvytku: Ukrayina [Goals adapted for Ukraine. Sustainable Development Goals: Ukraine]. Kyiv: Ministry for economic development and trade of Ukraine, $176 \mathrm{p}$. (in Ukrainian)

12. Official web-site of the Ministry of Agrarian Policy and Food of Ukraine. Available at: https://minagro.gov.ua/ua 